\title{
Mutational analysis of P-glycoprotein: suppression of caspase activation in the absence of ATP-dependent drug efflux
}

KM Tainton ${ }^{1}$, MJ Smyth ${ }^{1}$, JT Jackson ${ }^{1}$, JE Tanner ${ }^{1}$, L Cerruti ${ }^{2}$, SM Jane ${ }^{2}$, PK Darcy ${ }^{1}$ and RW Johnstone ${ }^{*, 1}$

${ }^{1}$ Cancer Immunology Program, The Peter MacCallum Cancer Centre, Trescowthick Research Laboratories, East Melbourne, Victoria, Australia

2 Rotary Bone Marrow Research Laboratory, Royal Melbourne Hospital Research Foundation, Parkville, Victoria, Australia

* Corresponding author: RW Johnstone, Cancer Immunology Program, The Peter MacCallum Cancer Centre, Trescowthick Research Laboratories, Smorgon Family Building, St Andrews Place, East Melbourne 3002, Victoria, Australia; Tel: + 61-9-9656-3727; Fax: +61-3-9656-1411;

E-mail: r.johnstone@pmci.unimelb.edu.au

Received 06.8.03; revised 21.1.04; accepted 03.2.04; published online 07.5.2004 Edited by Dr M Naito

\section{Abstract}

P-glycoprotein (P-gp) can induce multidrug resistance (MDR) through the ATP-dependent efflux of chemotherapeutic agents. We have previously shown that P-gp can inhibit nondrug apoptotic stimuli by suppressing the activation of caspases. To determine if this additional activity is functionally linked to ATP hydrolysis, we expressed wild-type and ATPase-mutant P-gp and showed that cells expressing mutant P-gp could not efflux chemotherapeutic drugs but remained relatively resistant to apoptosis. CEM lymphoma cells expressing mutant $P$-gp treated with vincristine showed a decrease in the fraction of cells with apoptotic morphology, cytochrome $c$ release from the mitochondria and suppression of caspase activation, yet still accumulated in mitosis and showed a loss of clonogenic potential. The loss of clonogenicity in vincristine-treated cells expressing mutant P-gp was associated with accumulation of cells in mitosis and the presence of multinucleated cells consistent with mitotic catastrophe. The antiapoptotic effect of mutant P-gp was not affected by antibodies that inhibit the efflux function of the protein. These data are consistent with a dual activity model for P-gp-induced MDR involving both ATPasedependent drug efflux and ATPase-independent inhibition of apoptosis. The structure-function analyses described herein provide novel insight into the mechanisms of action of P-gp in mediating MDR.

Cell Death and Differentiation (2004) 11, 1028-1037.

doi:10.1038/sj.cdd. 4401440

Published online 7 May 2004

Keywords: P-glycoprotein; drug resistance; caspase; apoptosis

Abbreviations: MDR, multidrug resistance; P-gp, P-glycoprotein; MRP, multidrug resistance associated protein; $A B C$, ATP-binding cassette; CFTR, cystic fibrosis transmembrane conductance regulator; Rh123, rhodamine 123; pHi, intracellular $\mathrm{pH}$; cyt $c$, cytochrome $c$; TNF, tumor necrosis factor

\section{Introduction}

Multidrug resistance (MDR) is a well-defined phenomenon of cross-resistance of tumor cells to a number of anticancer agents following exposure to one such drug. ${ }^{1}$ MDR is often associated with the expression of P-glycoprotein (P-gp), a membrane-bound protein comprising 12 transmembrane domains, two ATP binding/hydrolysis sites and a phosphorylated linker region, that can efflux a range of structurally and functionally diverse compounds. ${ }^{1} \mathrm{P}$-gp is expressed at the apical membranes of the liver, kidney and gut, and at the blood-brain and blood-testis barriers, ${ }^{2,3}$ which suggests a physiological role for $\mathrm{P}$-gp in protecting vital organs from xenotoxic agents. Cancers arising from these tissues are often intrinsically resistant to various chemotherapeutic regimes, possibly due to the functional expression of P-gp. However, $\mathrm{P}$-gp is also constitutively expressed on hemopoietic stem cells, natural killer (NK) cells, antigen-presenting dendritic cells (DC) and T- and B lymphocytes ${ }^{4}$ and its function on these cells remains unclear.

Transfection studies have clearly shown that overexpression of $\mathrm{P}$-gp can confer $\mathrm{MDR}^{5}$ and a number of models have been proposed to explain the mechanism of action of $P$-gp in mediating drug resistance. Drug-stimulated ATPase activity of $P$-gp has been demonstrated in isolated plasma membrane vesicles, ${ }^{6}$ reconstituted liposomes, ${ }^{7}$ insect cells, ${ }^{8}$ and mammalian cells ${ }^{9}$ and drug transport has been coupled to ATP hydrolysis. ${ }^{10,11}$ The traditional model for P-gp function was one where P-gp acted as a 'drug pump' to export drugs out of the cell against a concentration gradient. This has been further expanded to the 'flippase' model that attempted to explain how $\mathrm{P}$-gp could remove a range of structurally diverse drugs without an apparent substrate specificity. ${ }^{12,13}$

We and others have demonstrated that functional P-gp can confer resistance to apoptosis induced by diverse nondrug stimuli including Fas and TNF, UVB- and $\gamma$-irradiation and serum starvation. ${ }^{14-18}$ We showed that $P$-gp could inhibit the activation of caspases, key proapoptotic enzymes essential for the induction of apoptosis mediated by most chemotherapeutic drugs. ${ }^{19}$ Moreover, P-gp has been demonstrated to play a role in protecting primary acute myeloid leukemia cells from spontaneous apoptosis, ${ }^{20,21}$ and may regulate activation-induced apoptosis of primary $\mathrm{T}$ lymphocytes. ${ }^{22}$ In addition, overexpression of human MDR1 in primary mouse hemopoietic stem cells resulted in expansion of the stem cells in vitro and in vivo, and in the development of a myeloproliferative syndrome in transplanted mice. ${ }^{23,24}$ Taken together, these studies provide evidence for a more general antiapoptotic function for P-gp, however, the molecular events 
underpinning this proposed function have not yet been carefully assessed.

Active efflux of cytotoxic drugs by $P$-gp is associated with ATP hydrolysis ${ }^{10,11}$ and single amino-acid substitutions (Lys to Met) within the Walker A nucleotide binding motifs of either or both ATP binding sites is sufficient to eliminate P-gpmediated ATP hydrolysis while still permitting ATP binding. ${ }^{25}$ While it has been assumed that the direct link between ATP hydrolysis and drug efflux fully explains the functional effect of $\mathrm{P}-\mathrm{gp}$ in mediating resistance to chemotherapeutic drugs and other stimuli, this has not been formally assessed and is the basis for the studies described herein.

We have produced human CEM T-cell lymphoma lines expressing GFP (CEM-GFP), GFP and wild-type P-gp (CEM$\mathrm{P}-\mathrm{gp}^{\mathrm{WT}}$ ), or GFP and a mutant form of P-gp with lysine to methionine mutations within the Walker $A$ motifs at positions 433 and 1076 (CEM-P-gp ${ }^{\mathrm{MM}}$ ). As expected, CEM-P-gp ${ }^{\mathrm{WT}}$ cells were resistant to death induced by a range of different chemotherapeutic agents, and consistent with previous data, ${ }^{17}$ CEM-P-gp ${ }^{\text {WT }}$ cells were also resistant to apoptosis following growth factor withdrawal. Disruption of P-gp ATPase activity completely inhibited the ability of CEM-P-gp ${ }^{M M}$ cells to efflux drugs; however, these cells still showed resistance to apoptosis induced by a vast array of apoptotic drugs including P-gp-substrate and -nonsubstrate drugs, and to apoptosis mediated by serum starvation. As we have previously shown, $\mathrm{P}-\mathrm{gp}^{\mathrm{WT}}$ suppressed caspase activation. Importantly, $\mathrm{P}-\mathrm{gp}^{\mathrm{MM}}$ also inhibited drug-induced caspase activation with the degree of inhibition correlating with sensitivity of the cells to apoptosis. Interestingly, drug-treated P-gp ${ }^{\mathrm{MM}}$ cells exhibited altered cell cycle progression with accumulation of cells in G2/ $M$ and morphological changes consistent with aberrant mitosis that correlated with a loss in clonogenic potential. These data indicated for the first time that $P$-gp regulated drug-induced caspase activation and apoptosis in the absence of its efflux function and provided compelling evidence for an efflux-independent antiapoptotic role for P-gp.

\section{Results}

\section{Cellular expression of wild-type and mutant P-glycoprotein using retroviral gene transduction}

The MSCV retroviral vector was used to coexpress GFP and wild-type or ATPase-mutant P-gp, and cells were selected by flow cytometry. As shown in Figure 1 (top panel), cells transduced with MSCV alone (CEM-GFP), MSCV-MDR1 (CEM-P-gp ${ }^{W T}$ ) and two clones transduced with MSCVMDR1 ${ }^{\mathrm{K} 433 \mathrm{M} / \mathrm{K} 1076 \mathrm{M}}$ (CEM-P-gp ${ }^{\mathrm{MM}-3}$ and CEM-P-gp ${ }^{\mathrm{MM}-32}$ ) were obtained and expressed equivalent levels of intracellular GFP. In addition, CEM-P-gp ${ }^{W T}$, CEM-P-gp ${ }^{M M-3}$ and CEM-P$\mathrm{gp}^{\mathrm{MM}-32}$ cells expressed equivalent levels of wild-type and mutant $P$-gp respectively, while CEM-GFP expressed no detectable P-gp (Figure 1 bottom panel). All cells were assessed regularly to ensure stable expression of GFP and $\mathrm{P}$-gp. To confirm that the desired form of P-gp was expressed, the regions encoding $\mathrm{K} 433 \mathrm{M}$ and $\mathrm{K} 1076 \mathrm{M}$ substitutions were amplified by PCR using cDNA obtained from CEM-P-gp ${ }^{\mathrm{WT}}$, CEM-P-gp ${ }^{\mathrm{MM}-3}$ and CEM-P-gp ${ }^{\mathrm{MM}-32}$ cells and sequenced

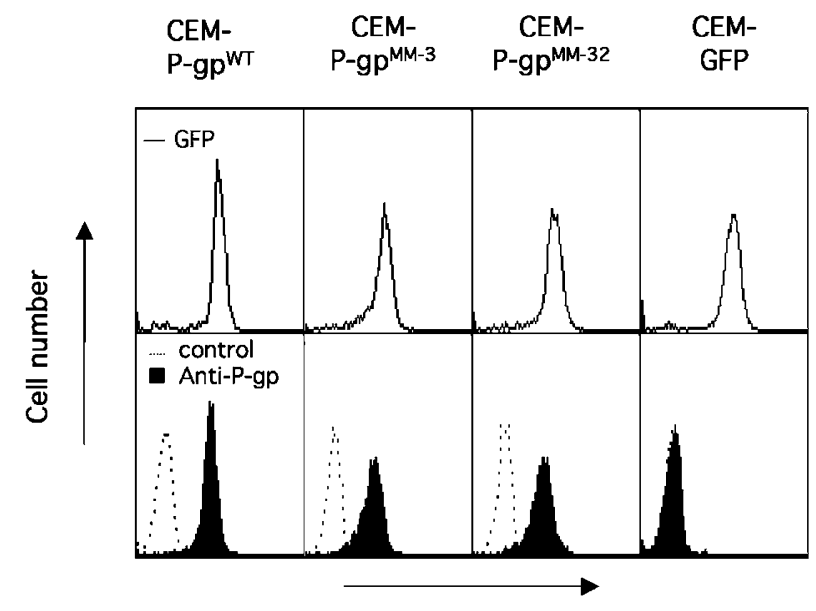

Log Fluorescence

Figure 1 Cell surface expression of GFP and P-gp. CEM-GFP, CEM-P-gp ${ }^{W T}$, CEM-P-gp ${ }^{\mathrm{MM}-3}$ and CEM-P-gp ${ }^{\mathrm{MM}-32}$ cells were incubated with MRK16 Mab specific to P-gp (filled histograms) or isotype control antibody (dotted line) and phycoerythrin-labeled anti-mouse secondary antibodies. Cell surface P-gp and intracellular GFP expression (solid line) was detected by flow cytometry

(data not shown). The growth rates of the four cell lines were also assessed and found to be identical (data not shown).

\section{Common P-gp substrates accumulate in CEM-GFP and CEM-P-gp ${ }^{\text {MM }}$ cells}

It was expected that P-gp WT ${ }^{W T}$ would be capable of effluxing substrates while $\mathrm{P}-\mathrm{gp}^{\mathrm{MM}}$ would be defective for this function and this was tested by assessing the uptake of the P-gp substrate Rh123 (Figure 2a). As expected, the CEM-P-gp WT cells exhibited a lower accumulation of Rh123 due to the ability of wild-type P-gp to efflux the substrate from the cells, while CEM-GFP cells were strongly positive for Rh123. Moreover, CEM-P-gp ${ }^{\mathrm{MM}}$ cells incubated with Rh123 showed a fluorescence profile indistinguishable from the CEM-GFP cells. Addition of the $P$-gp reversal agent verapamil resulted in increased Rh123 retention in CEM-P-gp ${ }^{W T}$ cells and had little effect on the CEM-P-gp ${ }^{M M}$ or CEM-GFP cells.

While Rh123 efflux has been used successfully to measure the efflux capacity of $P$-gp, ${ }^{26,27}$ it has been suggested that this assay may not accurately reflect the drug efflux function of $P$ gp. ${ }^{28} \mathrm{We}$, therefore, assessed the accumulation of radiolabeled vinblastine $\left({ }^{3} \mathrm{H}-\mathrm{Vb}\right)$ in CEM-GFP, CEM-P-gp ${ }^{W T}$ and CEM-P-gp ${ }^{\mathrm{MM}}$ cells. As shown in Figure $2 \mathrm{~b}$, the accumulation of ${ }^{3} \mathrm{H}-\mathrm{Vb}$ correlated with that seen using Rh123. To determine if there were differences in the rate of drug efflux in CEM-P. $\mathrm{gp}^{\mathrm{WT}}$, CEM-P-gp ${ }^{\mathrm{MM}}$ and CEM-GFP cells, we performed a drug efflux time course assay by incubating cells with ${ }^{3} \mathrm{H}-\mathrm{Vb}$ and allowing the cells to efflux the radiolabeled drug against a concentration gradient of unlabeled vinblastine. Figure $2 \mathrm{c}$ shows that uptake of ${ }^{3} \mathrm{H}-\mathrm{Vb}$ was identical in CEM-GFP and CEM-P-gp ${ }^{\mathrm{MM}}$ cells and there was an equivalent loss of labeled drug over the 30 min time course. In contrast, CEM-P-gp WT cells showed less initial uptake of ${ }^{3} \mathrm{H}-\mathrm{Vb}$ and the final concentration of ${ }^{3} \mathrm{H}-\mathrm{Vb}$ was lower than in CEM-GFP and CEM-P-gp ${ }^{\mathrm{MM}}$ cells after efflux against a concentration 
a
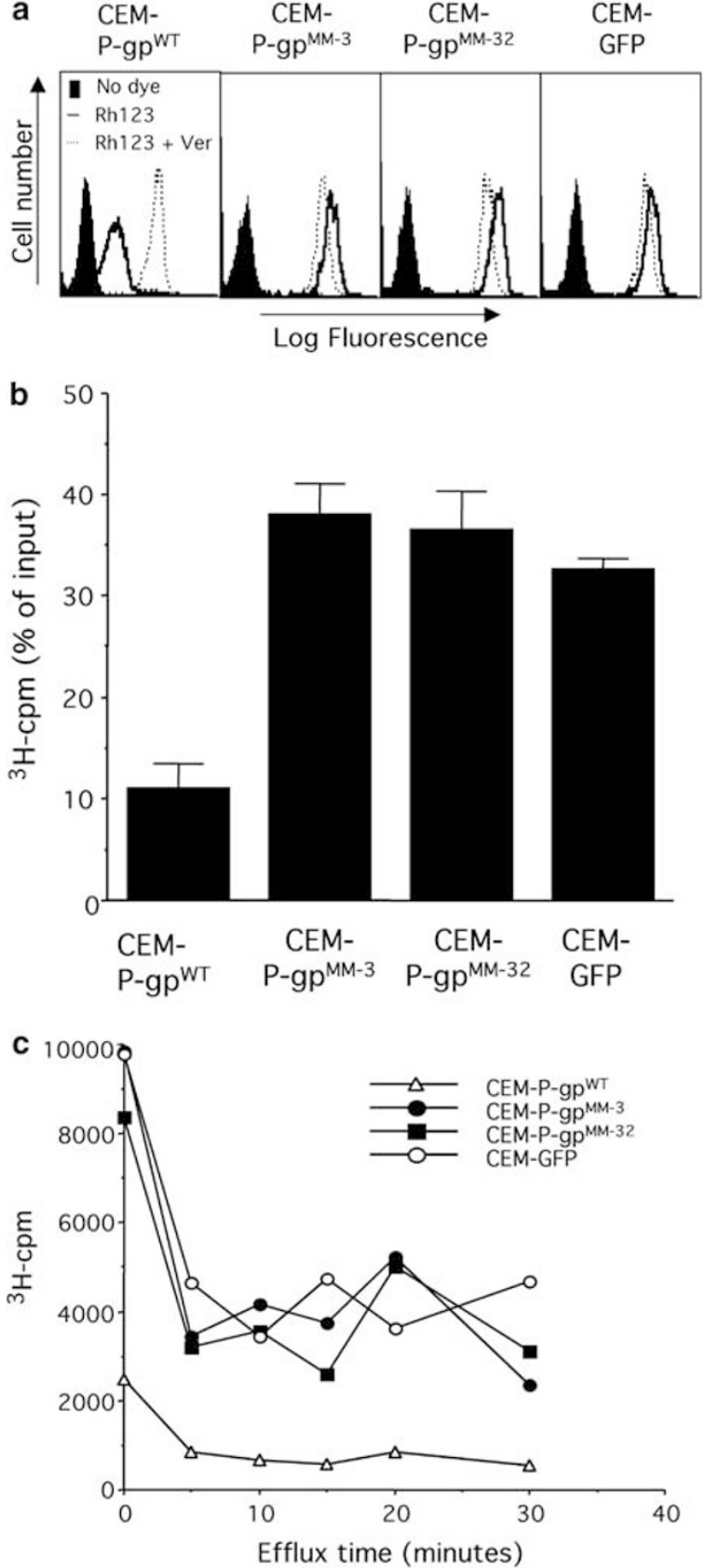

Figure 2 P-gp substrates accumulate in CEM-P-gp ${ }^{M M}$ cells. (a) Cells were untreated (filled histograms) or incubated with rhodamine123 (Rh123) alone (solid line) or with $10 \mu \mathrm{M}$ verapamil (Ver) (dotted lines) for $20 \mathrm{~min}$ at $37^{\circ} \mathrm{C}$ and then pelleted and incubated for 20 min with or without Ver in the absence of Rh123. (b) Cells were incubated in RPMl containing $25 \mathrm{ng} / \mathrm{ml}$ tritium labeled vinblastine $\left({ }^{3} \mathrm{H}-\mathrm{Vb}\right)$ for $1 \mathrm{~h}$ at $37^{\circ} \mathrm{C}$. The cells were then lysed and read on a beta counter. The data were analyzed as a percentage of input ${ }^{3} \mathrm{H}-\mathrm{Vb}$. (c) Cells were incubated in RPMI containing $25 \mathrm{ng} / \mathrm{ml}^{3} \mathrm{H}-\mathrm{Vb}$ for $1 \mathrm{~h}$ at $37^{\circ} \mathrm{C}$, then washed and resuspended in RPMl containing $25 \mu \mathrm{g} / \mathrm{ml}$ unlabeled $\mathrm{Vb}$. Aliquots were taken over the time course, the cells lysed and read in a beta counter. Results are expressed as ${ }^{3} \mathrm{H}-\mathrm{cpm}$ per aliquot. All data are representative of at least three separate experiments

gradient of unlabeled $\mathrm{Vb}$. These data clearly demonstrated that in transduced CEM cells, P-gp transported substrates including the chemotherapeutic drug vinblastine and the fluorescent dye Rh123 in an ATP-dependent manner.

\section{CEM-P-gp ${ }^{\mathrm{WT}}$ and CEM-P-gp ${ }^{\mathrm{MM}}$ confer resistance to vincristine-induced apoptosis}

To determine if ATPase-defective P-gp affected drug-induced apoptosis, we tested CEM-GFP, CEM-P-gp ${ }^{\text {WT }}$, CEM-P-gp ${ }^{\text {MM- }}$ ${ }^{3}$ and CEM-P-gp ${ }^{M M-32}$ cells for sensitivity to apoptosis induced by the substrate drug vincristine. ${ }^{10}$ As expected, assessment of cell death by annexin $V$ staining demonstrated that CEMGFP cells were sensitive to apoptosis induced by vincristine, while CEM-P-gp ${ }^{\text {WT }}$ cells were resistant (Figure 3a). Unexpectedly, CEM-P-gp ${ }^{\mathrm{MM}-3}$ and CEM-P-gp ${ }^{\mathrm{MM}-32}$ cells were also resistant to vincristine-induced apoptosis, although they were not as resistant as the CEM-P-gp ${ }^{\mathrm{WT}}$ cells. These results were confirmed by trypan blue-exclusion assays (data not shown).

Our data showed that mutation of the ATPase sites within $\mathrm{P}$-gp resulted in the accumulation of P-gp substrate compounds within CEM-P-gp ${ }^{M M}$ due to an inability to efflux substrates. However, the results shown in Figure 3a demonstrated that $\mathrm{P}-\mathrm{gp}^{\mathrm{MM}}$ still conferred resistance to vincristine. It was formally possible that while $\mathrm{P}-\mathrm{gp}^{\mathrm{MM}}$ was unable to efflux substrate drugs, it could still bind to and sequester the drug,
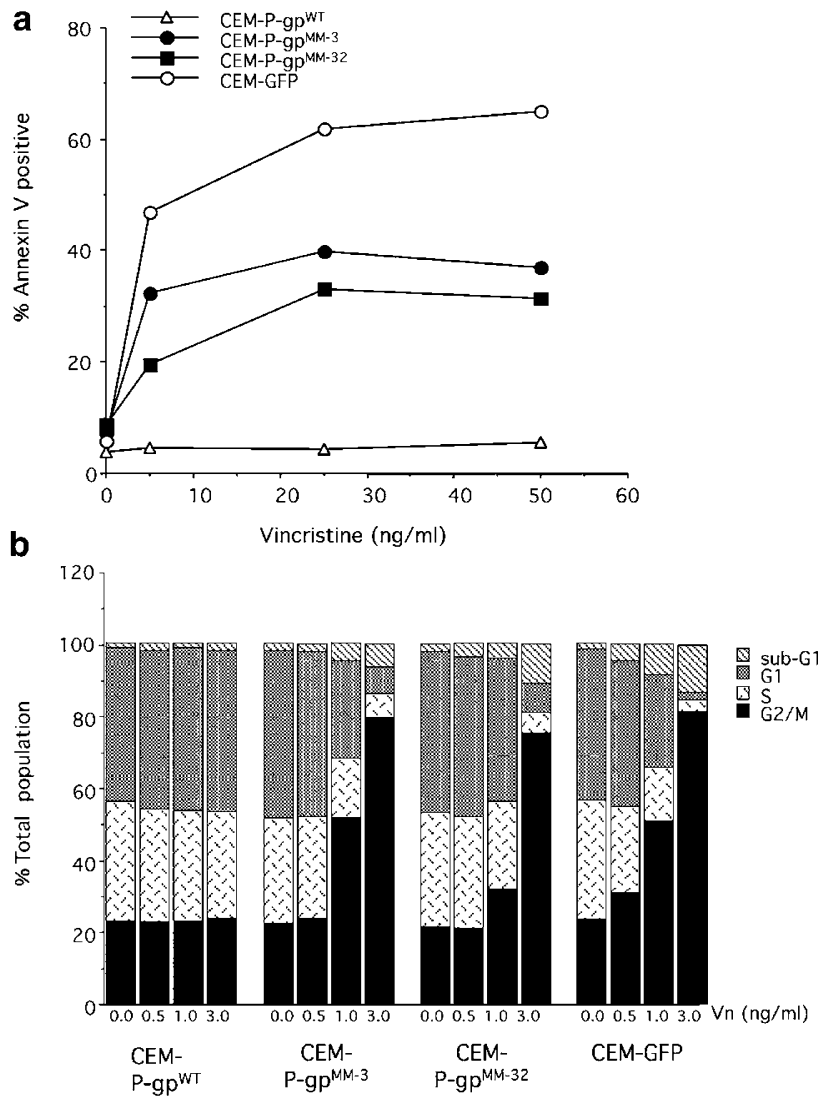

Figure 3 CEM-P-gp ${ }^{M M}$ are resistant to vincristine-induced apoptosis. (a) Cells were treated with vincristine $(\mathrm{Vn})$ for $24 \mathrm{~h}$ and labeled with alexa-568 conjugated annexin to label exposed phosphatidylserine as a readout for apoptosis. Annexin binding was assessed by flow cytometry. Data are representative of at least three separate experiments. (b) Cells were treated with $0.5-3.0 \mathrm{ng} / \mathrm{ml}$ vincristine for $24 \mathrm{~h}$, fixed in $50 \%$ ethanol and stained with propidium iodide. DNA content was analyzed by flow cytometry. The populations of cells in the $G_{1}, S$ and $G_{2} / M$ phases of the cell cycle, or with a DNA content less than $G_{1}$ (sub- $G_{1}$ ) are indicated 
thereby inhibiting drug-target interaction and affecting drug action. Vincristine is a microtubule-depolymerizing agent that at relatively low concentrations induces the accumulation of cells in the G2/M phase of the cell cycle. ${ }^{29,30}$ To determine if $\mathrm{P}-\mathrm{gp}^{\mathrm{MM}}$ inhibited the ability of vincristine to interact with its molecular targets, we analyzed the effect of low concentrations of vincristine on the cell cycle profile in CEM-GFP, CEMP-gp ${ }^{W T}$, CEM-P-gp ${ }^{M M-3}$ and CEM-P-gp ${ }^{M M-32}$ cells. Consistent with the finding that vincristine is effectively effluxed by wildtype P-gp, there was little or no effect on the cell cycle profiles of CEM-P-gp ${ }^{W T}$ cells treated with up to $3.0 \mathrm{ng} / \mathrm{ml}$ vincristine (Figure 3b). However, CEM-GFP and CEM-P-gp ${ }^{\mathrm{MM}}$ cells showed an equivalent dose-dependant increase in the percentage of cells in $\mathrm{G} 2 / \mathrm{M}$, indicating that in these cells, exclusion or sequestration of drug was not the mechanism by which P-gp ${ }^{M M}$ inhibited vincristine-induced apoptosis.

We next sought to determine whether the inhibition of apoptosis in CEM-P-gp ${ }^{\mathrm{MM}-3}$ and CEM-P-gp ${ }^{\mathrm{MM}-32}$ cells seen in short-term $(24 \mathrm{~h})$ assays translated to a long-term increase in cell viability. CEM-GFP, CEM-P-gp ${ }^{\mathrm{WT}}$, and CEM-P-gp ${ }^{\mathrm{MM}}$ cells were treated for 4 days with vincristine and apoptosis was assessed. Figure $4 a$ shows that CEM-P-gp ${ }^{M M}$ cells were consistently less sensitive to vincristine-induced apoptosis over the entire time course, compared to CEM-GFP cells. However, unlike CEM-P-gp ${ }^{\text {WT }}$ cells, the antiapoptotic effect of mutant P-gp was overcome with time. It is therefore possible that ATPase-mutant P-gp altered the kinetics of vincristineinduced apoptosis but did not completely block it. Alternatively, it is possible that other cell death pathways may not be affected by $\mathrm{P}-\mathrm{gp}^{\mathrm{MM}}$, ultimately resulting in loss of viability of drug-treated cells expressing this mutant form of P-gp. To further assess the effect of $\mathrm{P}-\mathrm{gp}^{\mathrm{MM}}$ on the long-term growth and survival of vincristine-treated cells, clonogenic assays were performed. Consistent with the data shown above, approximately $60 \%$ of CEM-P-gp ${ }^{\mathrm{WT}}$ cells retained their clonogenic potential following a $24 \mathrm{~h}$ incubation with vincristine (Figure 4b). However, despite the relative loss in sensitivity of CEM-P-gp ${ }^{\mathrm{MM}}$ cells to vincristine-induced apoptosis, their clonogenic potential was severely affected and these cells appeared as sensitive as CEM-GFP cells in this assay.

Clonogenic assays provide a readout for cell growth and/or survival, and our data demonstrated that while $\mathrm{P}-\mathrm{gp}^{\mathrm{MM}}$ enhanced cell viability following short-term treatment with chemotherapeutic drug, the clonogenic potential of CEM-P$\mathrm{gp}^{\mathrm{MM}}$ cells was attenuated. This could occur due to the
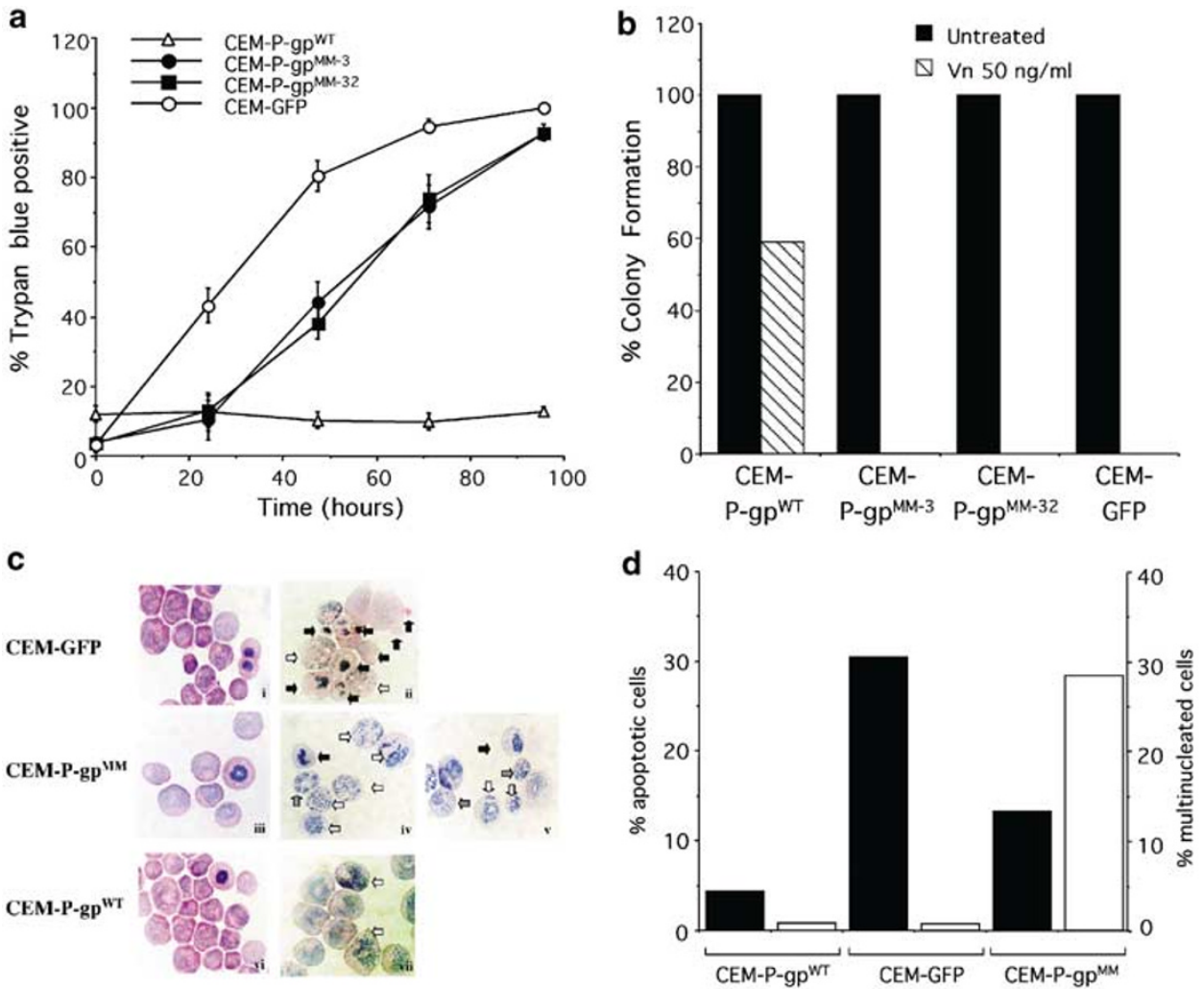

Figure 4 Resistance mediated by $\mathrm{P}-\mathrm{gp}^{\mathrm{MM}}$ is not maintained long term. (a) Cells were treated with $25 \mathrm{ng} / \mathrm{ml}$ vincristine and cell viability was assessed by trypan blueexclusion assays at $24 \mathrm{~h}$ intervals. Data were calculated are the mean \pm S.E. of quadruplicate samples and are representative of at least two different experiments. (b) Cells were treated for $24 \mathrm{~h}$ with $50 \mathrm{ng} / \mathrm{ml}$ vincristine and equal numbers of cells were then plated in soft agar for 2 weeks before the colonies were counted. Data are representative of at least three separate experiments. (c) Comparison of the morphological changes in untreated CEM-GFP(i), CEM-P-gp ${ }^{\mathrm{MM}}$ (iii) and CEM-P-gp ${ }^{\mathrm{WT}}$ (vi) cells treated with $50 \mathrm{ng} / \mathrm{ml}$ vincristine for $24 \mathrm{~h}$ (ii, iv, v, vii). Cells were stained with hematoxylin and eosin and assessed by oil immersion under light microscopy $(\times 630)$. Apoptotic cells are shown by black arrows, cells containing disorganized chromosomes in a loosely separated and dispersed distribution suggestive of mitotic arrest are shown by white arrows and multinucleated cells characteristic of mitotic catastrophe are shown by gray arrows. (d) The percentage of cells with morphological characteristics of apoptosis (black bars) or with multiple nuclei (white bars) was quantitated by counting at least 100 cells in multiple fields of view 
remaining, albeit slower, apoptotic capacity of chemotherapeutic drugs in CEM-P-gp ${ }^{\mathrm{MM}}$ cells, by the induction another form of cell death not affected by $\mathrm{P}-\mathrm{gp}^{\mathrm{MM}}$, and/or the maintenance of drug-mediated cytostatic activity in these cells. It has been previously shown that wild-type P-gp can inhibit radiation-induced apoptosis, yet increased mitotic catastrophe and senescence in radiation-damaged cells. ${ }^{18}$ It is unlikely that the loss of clonogenicity of vincristine-treated CEM-P-gp ${ }^{\mathrm{MM}}$ cells is due to the induction of senescence as vinca alkaloids are poor inducers of senescence. ${ }^{31}$ Moreover, almost all of the vincristine-treated CEM-P-gp ${ }^{\mathrm{MM}}$ cells lose their plasma membrane integrity over time (Figure 4a), indicating that a loss of cell viability, rather than a loss of cell proliferation, is primarily responsible for the loss of clonogenicity. We therefore assessed the possible induction of mitotic catastrophe in vincristinetreated CEM-P-gp ${ }^{\mathrm{MM}}$ cells (Figure 4c). A large proportion of CEM-GFP cells treated with vincristine showed morphological changes such as DNA condensation and cell shrinkage that are characteristic of apoptosis (Figure 4c ii) while drug-treated CEM-P-gp ${ }^{W T}$ cells remained relatively unchanged (Figure 4c vii). By contrast, a large proportion of vincristine-treated CEM-P-gp ${ }^{\mathrm{MM}}$ cells had morphologies characteristic of cells undergoing aberrant mitosis with some cells becoming multinucleated which is consistent with cells undergoing mitotic catastrophe ${ }^{18,32}$ (Figure $4 \mathrm{c}$ iv, v). Consistent with our previous data, treatment with vincristine over $24 \mathrm{~h}$ induced less apoptosis in CEM-P-gp ${ }^{\mathrm{MM}}$ cells compared to CEM-GFP cells; however, $\mathrm{P}-\mathrm{gp}^{\mathrm{MM}}$ did not prevent the changes in mitosis induced by this drug. Quantitation of cells showing apoptotic or multinucleated morphologies confirmed that fewer vincristine-treated CEM$\mathrm{Pgp}^{\mathrm{MM}}$ cells underwent apoptosis and more showed a multinucleated phenotype compared to CEM-GFP cells that predominantly underwent apoptosis (Figure 4d) These data therefore indicate that $\mathrm{P}-\mathrm{gp} \mathrm{MM}^{\mathrm{MM}}$ can inhibit vincristine-induced apoptosis, but has no effect on the ability of this drug to deregulate mitosis and induce changes characteristic of mitotic catastrophe.

We and others had previously shown that the antiapoptotic activity of P-gp can be considerably reversed using specific anti-P-gp monoclonal antibodies. ${ }^{14,33}$ To test if these antibodies also inhibited the antiapoptotic function of the P-gp ATPase mutant, we preincubated the cells with the anti-P-gp antibodies MRK16 or UIC2 before incubation with vincristine and assessed apoptosis (Figure 5). Both antibodies were able to equivalently bind wild-type and mutant P-gp on CEM-P$\mathrm{gp}^{\mathrm{WT}}$ and CEM-P-gp ${ }^{\mathrm{MM}}$ cells, respectively (Figure 1a and data not shown). Preincubation of CEM-GFP or CEM-P-gp ${ }^{M M}$ cells with either UIC2 or MRK 16 had no significant effect on the relative sensitivity of these cells to vincristine-induced apoptosis. In contrast, both antibodies sensitized the CEM$\mathrm{P}-\mathrm{gp}^{\mathrm{WT}}$ cells to vincristine although the increase in apoptosis only reached levels equivalent to that seen in the CEM-P$\mathrm{gp}^{\mathrm{MM}}$ cells and never completely reversed the antiapoptotic effects of P-gp. Collectively, these data suggested that P-gp may have two mechanisms of action, one requiring ATPase activity that was inhibited by anti-P-gp antibodies, and the other occurring in the absence of ATPase activity and not affected by UIC2 or MRK16.

\section{CEM-P-gp ${ }^{\mathrm{WT}}$ and CEM-P-gp ${ }^{\mathrm{MM}}$ mediate resistance to a variety of substrate and nonsubstrate apoptotic stimuli}

To ensure that resistance to vincristine-induced apoptosis mediated by $\mathrm{P}-\mathrm{gp}^{\mathrm{MM}}$ was not restricted to that particular drug, we assessed the effect of other microtubule-targeting drugs (vinblastine, colchicine), as well as drugs such as doxorubicin and etoposide that target topoisomerase II (Table 1). These drugs are substrates for $\mathrm{P}-\mathrm{gp}^{34,35}$ (Figure $2 \mathrm{~b}, \mathrm{c}$ ) and as expected, expression of wild-type P-gp conferred resistance to apoptosis, while CEM-GFP cells were sensitive to these drugs. Importantly, CEM-P-gp ${ }^{\mathrm{MM}}$ cells showed an intermediate resistance phenotype to apoptosis induced by these diverse cytotoxic agents suggesting a common mechanism of apoptosis resistance mediated by ATPase-defective P-gp.

To separate the drug efflux activity of P-gp from its ATPaseindependent antiapoptotic activity, we determined the relative

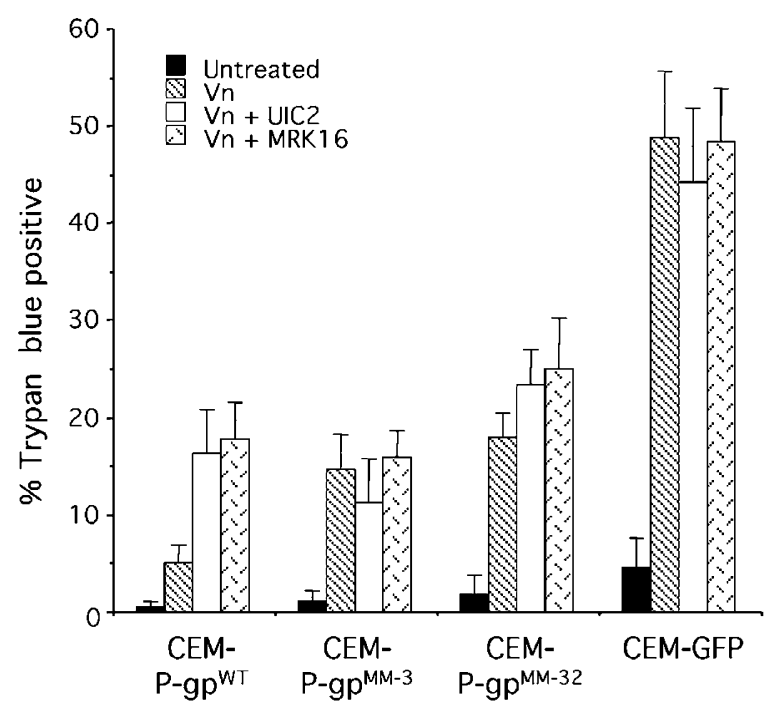

Figure 5 Specific antibodies cannot reverse vincristine resistance mediated by P-gp ${ }^{\mathrm{MM}}$. Cells were pretreated with either $16 \mu \mathrm{g} / \mathrm{ml}$ UIC2 or $100 \mu \mathrm{g} / \mathrm{ml}$ MRK16 for $1 \mathrm{~h}$ and then for $24 \mathrm{~h}$ with $50 \mathrm{ng} / \mathrm{ml}$ vincristine $(\mathrm{Vn})$. Death was assessed by trypan blue-exclusion assay. Data calculated are the mean \pm S.E. of quadruplicate samples and are representative of at least three different experiments

Table $1 \mathrm{P}-\mathrm{gp}^{\mathrm{MM}}$ can confer resistance to a number of P-gp substrate drugs

\begin{tabular}{lcccc}
\hline & $\begin{array}{c}\text { CEM-P- } \\
\text { gp }^{\text {WT }}\end{array}$ & $\begin{array}{c}\text { CEM-P- } \\
\text { gp }^{\text {MM-3 }}\end{array}$ & $\begin{array}{c}\text { CEM-P- } \\
\text { gp }^{\text {MM-32 }}\end{array}$ & CEM-GFP \\
\hline Vincristine & ++++ & ++ & ++ & - \\
Vinblastine & ++++ & ++ & ++ & - \\
Doxorubicin & ++++ & ++ & ++ & - \\
Colchicine & ++++ & ++ & ++ & - \\
Etoposide & ++++ & ++ & ++ & - \\
\hline
\end{tabular}

Cells were treated with drugs for $24 \mathrm{~h}$ (except doxorubicin, which was treated for $48 \mathrm{~h}$ ). Doses used were: vincristine $0-50 \mathrm{ng} / \mathrm{ml}$, vinblastine $0-25 \mathrm{ng} / \mathrm{ml}$, doxorubicin $0-250 \mathrm{ng} / \mathrm{ml}$, colchicine $0-20 \mathrm{ng} / \mathrm{ml}$, etoposide $0-1.0 \mu \mathrm{g} / \mathrm{ml}$. Analysis was by annexin-V-alexa 568 staining (vincristine, vinblastine, colchicine, etoposide) or trypan counting (doxorubicin). Resistance to drug-induced apoptosis is represented by ++++ while sensitivity is denoted by - . These data are representative of at least three separate experiments 

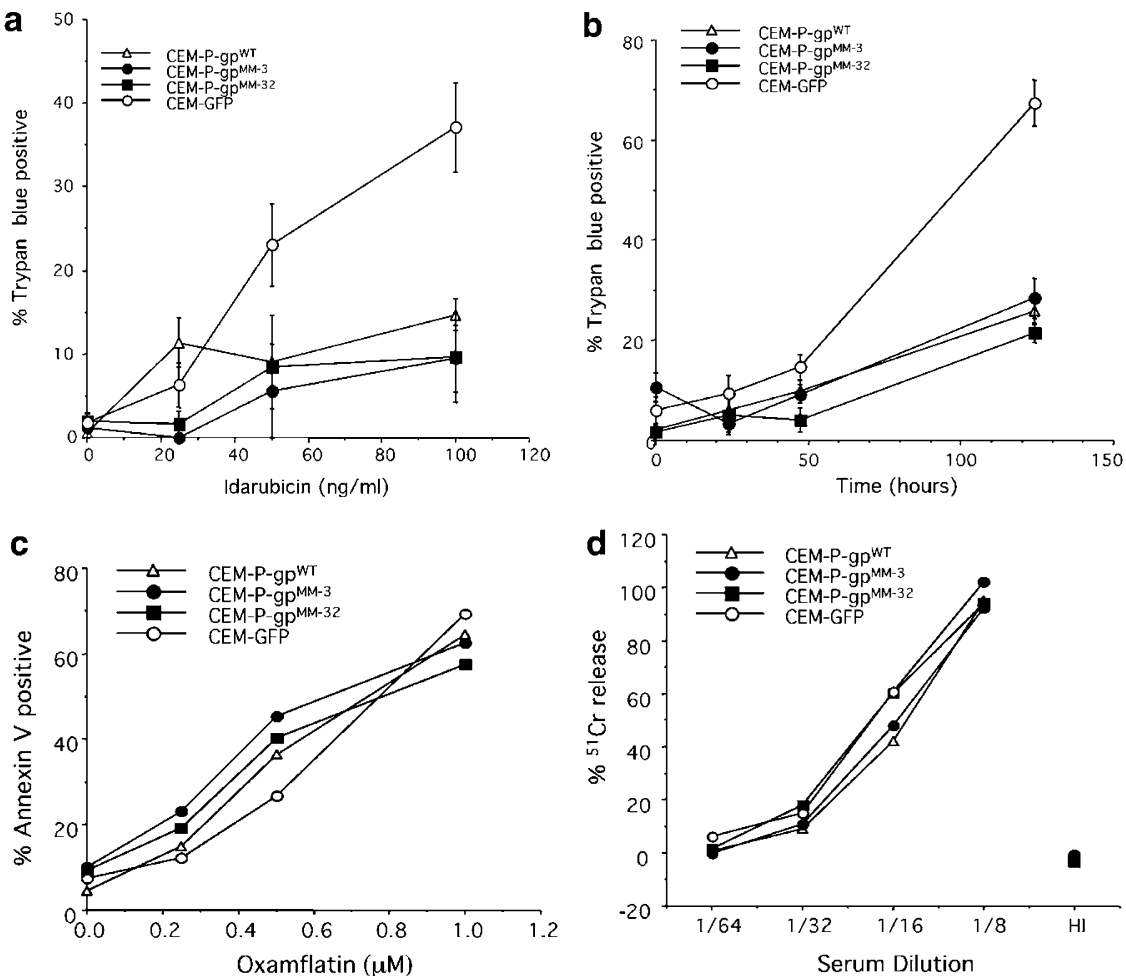

Figure $6 \mathrm{P}_{\mathrm{gp}} \mathrm{MM}^{\mathrm{MM}}$ mediates resistance to specific cell death stimuli. (a) Cells were treated with idarubicin for $24 \mathrm{~h}$ and cell viability was assessed by trypan blueexclusion assay. All data are calculated as the mean \pm S.E. of quadruplicate samples and are representative of at least three separate experiments. (b) Cells were grown in RPMI containing $1 \%$ FCS and cell viability was assessed by trypan blue-exclusion assay at $24 \mathrm{~h}$ intervals for $120 \mathrm{~h}$. (c) Cells were treated with oxamflatin for $24 \mathrm{~h}$ and labeled with alexa-568 conjugated annexin. Annexin binding was assessed by flow cytometry. (d) ${ }^{51} \mathrm{Cr}$ labeled cells were treated for $4 \mathrm{~h}$ with diluted normal rabbit serum containing active or heat-inactivated $(\mathrm{HI})$ complement as well as endogenous antibodies to the CEM cells. Data are representative of at least three separate experiments

sensitivity of CEM-GFP, CEM-P-gp ${ }^{\mathrm{WT}}$ and CEM-P-gp ${ }^{\mathrm{MM}}$ cells to apoptosis induced by idarubicin, which is a poor substrate for wild-type P-gp. ${ }^{36}$ As shown in Figure 6a, CEM-GFP cells were highly sensitive to idarubicin-induced apoptosis, while CEM-P-gp ${ }^{W T}$, CEM-P-gp ${ }^{M M-3}$ and CEM-P-gp ${ }^{M M-32}$ cells were significantly less sensitive. Importantly, there was no difference in the relative sensitivity of cells expressing wild type or ATPase mutant $P$-gp to idarubicin. To further demonstrate this additional efflux-independent mechanism of apoptosis resistance mediated by P-gp, we assessed the effect of serum starvation on these cells. It was previously shown that wildtype P-gp conferred resistance to apoptosis induced by growth factor deprivation ${ }^{17}$ and we therefore assessed whether efflux-deficient $\mathrm{P}$-gp affected this function. As shown in Figure 6b, both CEM-P-gp ${ }^{W T}$ and CEM-P-gp ${ }^{M M}$ cells were similarly resistant to apoptosis following growth factor withdrawal. In contrast, CEM-GFP cells were sensitive to death induced by this stimulus. Thus, in circumstances where the drug efflux activity of P-gp was either circumvented (i.e. by idarubicin) or played no role (i.e. factor withdrawal) in regulating apoptosis, both wild type and mutant forms of $\mathrm{P}$ gp conferred significant and similar resistance to apoptosis. These data were consistent with a 'dual activity' model for Pgp-mediated drug resistance whereby both an ATPasedependent drug efflux activity and an efflux-independent activity account for the overall resistance to drug-induced apoptosis.
To ensure that the antiapoptotic effects, we observed in CEM-P-gp ${ }^{W T}$ and CEM-P-gp ${ }^{M M}$ cells were not due to a general resistance to cell death, we treated the cells with stimuli shown previously to kill P-gp-expressing cells. Oxamflatin is a histone deacetylase inhibitor previously shown to induce apoptosis in both P-gp expressing and nonexpressing cells. ${ }^{37}$ CEM-P-gp ${ }^{W T}$, CEM-P-gp ${ }^{M M}$ and CEM-GFP cells were equivalently sensitive to oxamflatininduced apoptosis, indicating that certain drugs were able to mediate death in these cells (Figure $6 \mathrm{c}$ ). We have recently reported that $\mathrm{P}$-gp was unable to confer resistance to cell death by pore-forming proteins such as complement, perforin and pneumolysin. ${ }^{38}$ CEM-GFP, CEM-P-gp ${ }^{\mathrm{WT}}$, CEM-P-gp ${ }^{\mathrm{MM}-3}$ and CEM-P-gp ${ }^{\mathrm{MM}-32}$ cells were treated with normal rabbit serum as a source of complement and cell lysis was assessed by ${ }^{51} \mathrm{Cr}$ release (Figure $6 \mathrm{~d}$ ). Endogenous CEM cell-reactive antibodies within the rabbit serum were shown by flow cytometry to bind equivalently to all four transduced cell lines (data not shown) and enabled activation of the classical complement pathway and the rapid induction of cell lysis. All cell lines were equivalently sensitive to death induced by activated complement while heatinactivated serum had no effect on cell viability. These results suggested that wild type and ATPase-mutant forms of P-gp conferred resistance to cell death induced by specific stimuli, but do not provide nonspecific protection against all cytotoxic or cytolytic stimuli. 


\section{Expression of P-gp ${ }^{\mathrm{WT}}$ and P-gp ${ }^{\mathrm{MM}}$ can inhibit components of the apoptotic cascade}

We have previously shown that wild-type P-gp inhibited the activation of caspases, important proapoptotic enzymes activated in response to diverse apoptotic stimuli. ${ }^{14,15} \mathrm{We}$ therefore tested the effect of wild-type and mutant P-gp on the activation of important executioner caspases with DEVDase activity (i.e. caspase-3, caspase-7) following treatment of cells with vincristine that kills cells via caspases. ${ }^{15} \mathrm{~A}$ fluorogenic substrate specific for DEVDase caspases was used to screen for caspase activity in cell lysates from CEMGFP, CEM-P-gp ${ }^{W T}$, CEM-P-gp ${ }^{M M-3}$ and CEM-P-gp ${ }^{M M-32}$ cells treated with vincristine. As expected, caspase activation was almost completely blocked in cells expressing wild-type P-gp (Figure 7a), whereas robust caspase activity was observed in lysates from CEM-GFP cells treated with vincristine. In contrast, caspase activation was significantly attenuated in CEM-P-gp ${ }^{M M-3}$ and CEM-P-gp ${ }^{M M-32}$ cells, even though vincristine is not effluxed by ATPase-mutant P-gp (Figure 2). The cleavage of the caspase substrate PARP was also inhibited in vincristine-treated CEM-P-gp ${ }^{M M}$ cells (data not shown).
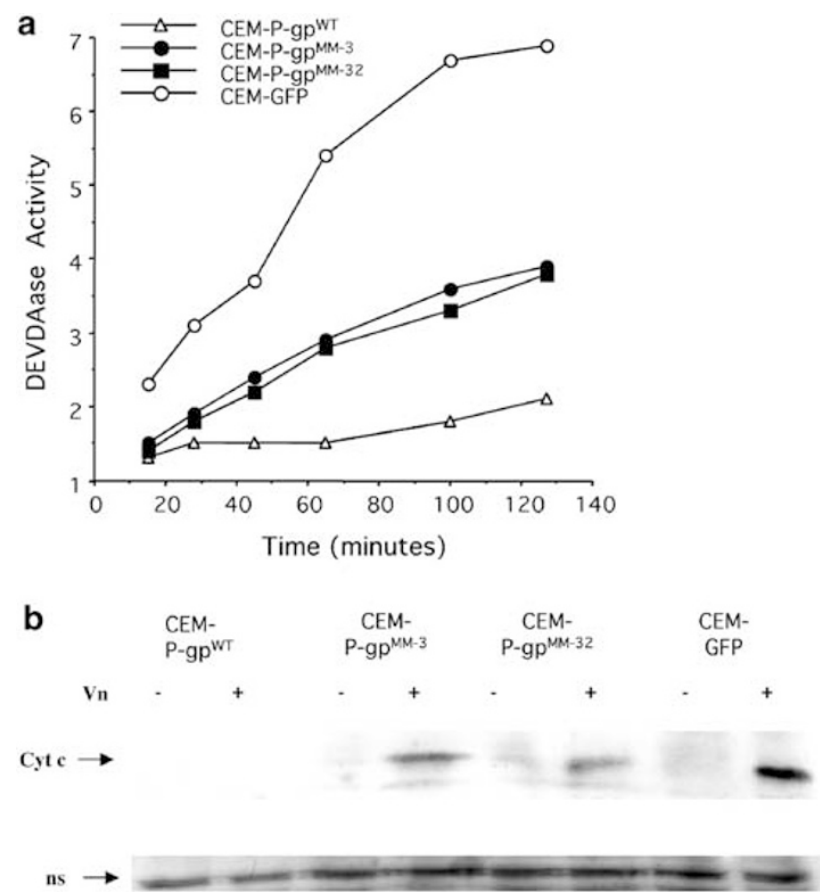

Figure $7 \quad \mathrm{P}$-gp $\mathrm{pM}^{\mathrm{MM}}$ inhibits drug-induced caspase activation and cytochrome $c$ release. (a) Cells were treated for $24 \mathrm{~h}$ with $80 \mathrm{ng} / \mathrm{ml}$ vincristine and protease inhibitor-free lysates made. $50 \mu \mathrm{g}$ of each lysates were mixed with the fluorogenic substrate DEVD-pNA and incubated at $37^{\circ} \mathrm{C}$, reading absorbance at $405 \mathrm{~nm}$ over a period of approximately $2 \mathrm{~h}$. Results were expressed as:

$$
(+ \text { drug }+ \text { pNA })-(+ \text { drug }-\mathrm{pNA}) /(- \text { drug }+ \text { pNA })-(- \text { drug }-\mathrm{pNA})
$$

(b) Cells were treated for $24 \mathrm{~h}$ with $25 \mathrm{ng} / \mathrm{ml}$ vincristine $(\mathrm{Vn})$ and cytosolic lysates prepared. Proteins were separated by SDS-PAGE (15\%) and Western blotting was performed using an anti-cytochrome $c$ antibody. As a control for equivalent protein loading in each lane, a nonspecific band detected with the anticytochrome $c$ antibody is shown (ns)
The intrinsic apoptotic pathway usually mediates activation of caspases following drug treatment. ${ }^{19}$ This requires the release of mitochondrial proteins including cytochrome $c$, Smac/DIABLO and HtrA2 into the cytosol to induce activation of effector caspases such as caspase-3 downstream of mitochondrial membrane perturbation. ${ }^{19}$ To determine whether P-gp was affecting cell death upstream or downstream of the mitochondria, we assessed the release of cytochrome $c$ from untreated and vincristine-treated CEMGFP, CEM-P-gp WT and CEM-P-gp ${ }^{\mathrm{MM}}$ cells by Western blotting cytosolic lysates using an anti-cytochrome $c$ antibody (Figure $7 \mathrm{~b}$ ). Little or no cytosolic cytochrome $c$ was seen in any of the untreated cells and as expected, significant amounts of cytosolic cytochrome $c$ were detected in vincristine-treated CEM-GFP cells, while none was observed in CEM-P-gp ${ }^{W T}$ cells. Consistent with the caspase activation data seen in Figure 7a, and with the apoptosis data observed in Figure 3, the release of cytochrome $c$ in vincristine-treated CEM-P-gp ${ }^{\mathrm{MM}-3}$ and CEM-P-gp ${ }^{\mathrm{MM}-32}$ cells was significantly less than that observed in CEM-GFP cells and more than that in CEM-P-gp ${ }^{\text {WT }}$ cells. Taken together, these data confirmed that ATPase-mutant P-gp conferred resistance to druginduced apoptosis by inhibiting the activation of caspases. The data also showed that mutant P-gp functioned upstream of mitochondrial membrane perturbation, leading to a decrease in the release of cytochrome $c$ and concomitant suppression of caspase activation.

\section{Discussion}

Drug resistance induced by $\mathrm{P}$-gp has been primarily linked to its extensively studied drug efflux activity. ${ }^{39}$ It is also possible that additional effects of $\mathrm{P}$-gp that suppress apoptosis may augment MDR mediated by P-gp. ${ }^{40}$ To functionally discriminate the drug-efflux effects of P-gp from other antiapoptotic effects, we have used a retroviral system to express wild-type $\mathrm{P}$-gp (P-gp ${ }^{\mathrm{WT}}$ ) and mutant $\mathrm{P}$-gp incapable of hydrolyzing ATP $\left(P-g p^{M M}\right)$. Our data indicated that although $P-g p^{M M}$ was incapable of effluxing well-characterized substrates, it was capable of suppressing drug-induced release of cytochrome $c$, caspase activation and apoptosis. While $\mathrm{P}-\mathrm{gp}^{\mathrm{MM}}$ significantly inhibited drug-induced apoptosis in short-term assays, drug-treated CEM-P-gp ${ }^{\mathrm{MM}}$ cells ultimately lost their clonogenic potential. This indicates that $\mathrm{P}-\mathrm{gp}^{\mathrm{MM}}$ can significantly alter the kinetics of cell death rather than completely blocking. Alternatively, drugs such as vincristine have been shown to mediate aberrant mitosis resulting in mitotic catastrophe and cell death ${ }^{31}$ and $\mathrm{P}-\mathrm{gp}^{\mathrm{MM}}$ did not inhibit the effects of vincristine on mitosis. The loss of clonogenicity in cells expressing mutant P-gp was associated with a large number of multinucleated cells indicative of mitotic catastrophe. Consistent with the data shown herein, drug-induced mitotic catastrophe has been shown to occur in the presence of the caspase inhibitor ZVAD-fmk ${ }^{32}$ indicating that this form of cell death does not require the activity of caspases such as caspase-3 which are effectively inhibited by ZVAD-fmk and by P-gp. As clonogenic assays are readouts for either induction of cell death or loss of cell proliferation, the loss of clonogenic potential in drug-treated CEM-P-gp ${ }^{\mathrm{MM}}$ cells could reflect 
either a loss in cell survival through delayed apoptosis, induction of mitotic catastrophe and/or impaired cell growth. Our results are consistent with others showing that P-gp can inhibit drug-induced apoptosis but does not affect other forms of cell death such as mitotic catastrophe. ${ }^{18}$

Our data demonstrated for the first time that an ATPasedefective form of P-gp incapable of effluxing substrate drugs still regulated drug-induced cell death. These findings were strengthened by our demonstration that apoptosis induced by idarubicin, a poor substrate for P-gp, ${ }^{36}$ was equivalently inhibited in CEM-P-gp ${ }^{W T}$ and CEM-P-gp ${ }^{M M}$ cells. Moreover, $\mathrm{P}-\mathrm{gp} \mathrm{WT}^{\mathrm{WT}}$ and $\mathrm{P}-\mathrm{gp}^{\mathrm{MM}}$ equivalently suppressed apoptosis mediated by growth factor withdrawal, consistent with previous demonstrations that wild-type P-gp provided a survival advantage to cells grown in reduced serum. ${ }^{17}$ Taken together, these data indicated that wild-type P-gp affected drug-induced apoptosis through two mechanisms, one mediated by ATP-dependent drug efflux and the other independent of ATPase activity, which may be unmasked by mutation of the Walker A ATPase site or by blocking efflux using antibodies or pharmacological inhibitors.

The specificity of the P-gp ${ }^{M M}$ effect on apoptosis was demonstrated by our finding that CEM- $\mathrm{P}-\mathrm{gp}^{\mathrm{MM}}$ cells were not resistant to all cell death stimuli. Interestingly, oxamflatin, a histone deacetylase inhibitor that we have recently shown can kill $\mathrm{P}$-gp ${ }^{+\mathrm{ve}}$ cells and is fully functional in the presence of the caspase inhibitory compound ZVAD-fmk, ${ }^{37}$ equivalently killed CEM-P-gp ${ }^{W T}$ and CEM-P-gp ${ }^{M M}$ cells. In addition, neither $\mathrm{P}$ $\mathrm{gp}^{\mathrm{WT}}$ nor $\mathrm{P}-\mathrm{gp}^{\mathrm{MM}}$ provided protection against complementmediated cell lysis indicating that cells expressing wild type or mutant P-gp were not generally insensitive to all forms of cell death. We have previously found that wild type, but not ATPase mutant P-gp can inhibit the activation of caspase-8 and subsequent apoptosis following ligation of the Fas death receptor. ${ }^{41}$ These data indicated that the apoptosis regulatory effects of $\mathrm{P}-\mathrm{gp}^{\mathrm{WT}}$ and $\mathrm{P}-\mathrm{gp}^{\mathrm{MM}}$ were specific and dependent on the death stimulus that was used. Clearly, $\mathrm{P}-g \mathrm{p}^{\mathrm{MM}}$ suppressed apoptosis mediated by certain stimuli (e.g. vincristine, doxorubicin, growth factor withdrawal), while having little or no effect in response to other stimuli (e.g. oxamflatin, Fas ligation).

It is presently unclear how P-gp affects caspase activation and apoptosis induced by certain stimuli. It has been shown that specific BH3-only proteins are required for apoptosis mediated by the intrinsic apoptotic pathway. For example, cells deficient in Bim are sensitive to death induced by dexamethasone and $\gamma$-irradiation, yet are insensitive to apoptosis induced by ionomycin, cytokine deprivation or taxol, ${ }^{42}$ while Bmf is necessary for apoptosis induced by anoikis. ${ }^{43}$ We have previously shown that apoptosis mediated by HDACi such as SAHA and oxamflatin, that are effective against $\mathrm{P}-\mathrm{gp}^{+\mathrm{ve}}$ cells, is characterized by the activation of Bid. ${ }^{37,44,45}$ In contrast, Bid played no role in death induced with staurosporine. ${ }^{45,46}$ Future analysis of the effects of wildtype and mutant P-gp on the activation and/or expression of $\mathrm{BH}$-only $\mathrm{Bcl}-2$ proteins will help delineate if $\mathrm{P}$-gp functionally regulates any of these proapoptotic proteins.

The results presented herein showed that a mutant form of P-gp incapable of effluxing cytotoxic drugs suppressed cytochrome $c$ release, activation of caspases and subsequent apoptosis. These findings have important implications for understanding the molecular events underpinning apoptosis resistance mediated by $\mathrm{P}$-gp and the development of chemotherapeutic drugs capable of circumventing the effects of P-gp. In addition, the data provide insight into the possible physiological function of P-gp, particularly in cells such as hemopoietic stem cells and immune cells where a toxin efflux role is not obvious. We are performing further structurefunction analyses to identify the molecular events necessary and sufficient for this novel efflux-independent function of P-gp.

\section{Materials and Methods}

\section{Cell culture}

CEM-CCRF were grown in RPMI medium 1640 and 293T cells were grown in DMEM supplemented with $10 \%(\mathrm{v} / \mathrm{v})$ fetal calf serum, $2 \mathrm{mM}$ glutamine (JRH Biosciences, Lenexa, KS), $100 \mathrm{U} / \mathrm{ml}$ penicillin and $100 \mu \mathrm{g} /$ $\mathrm{ml}$ streptomycin (CSL, Parkville, Australia). Vincristine, vinblastine, doxorubicin and etoposide were obtained from the Peter MacCallum Cancer Centre pharmacy. Colchicine was obtained from Sigma (St. Louis, MO, USA) and oxamflatin was kindly provided by Dr. Anthony Dear (Dept of Medicine, Box Hill Hospital, Australia). Naïve rabbit serum was used as a source of complement.

\section{Production of retrovirally transduced cell lines}

Production of MSCV-MDR1 (wild type) and MSCV-MDR1 (K433 M, K1076M) has been previously described. ${ }^{41}$ These constructs or MSCV alone were transfected into 293T cells with $P E Q$ and RD114 helper viruses by $\mathrm{CaPO}_{4}^{-}$precipitation. Packaging cells were assessed by flow cytometry for GFP expression, the viral supernatant added to CEM cells in the presence of $4 \mu \mathrm{g} / \mathrm{ml}$ polybrene (Sigma, St. Louis, MO, USA) and the top $5 \%$ of GFP-expressing cells isolated by cell sorting (BD Biosciences FACStar ${ }^{\text {PLUS }}$, North Ryde, Australia). Sorted cells were single cell cloned for stable expression. The cell surface expression of $P$-gp was assessed using the anti-P-gp monoclonal antibody MRK16 (Kamiya Biochemical, Thousand Oaks, CA, USA). For sequence verification of transduced wildtype and mutant MDR1, RNA was isolated using Trizol (Invitrogen, Carlsbad, CA, USA) and CDNA was made using Expand reverse transcriptase (Roche, Mannheim, Germany). Primers were designed to amplify across each mutation site. Primers for K433M were: (forward) TTGAAGGGTCTGAACCTG and (reverse) TGGTTGCAGGCCTCCATTTA. Primers for K1076M were: (forward) ATCCCAGTGCTTCAGGGA and (reverse) CCTTATTCCAAGCGGCTT. All were within the MDR1 gene except K1076 reverse, which was within the MSCV vector. PCR was performed using Platinum Pfx polymerase (Invitrogen, Carlsbad, CA, USA). Sequencing was performed using the same primers and the DYEET dye terminator mix (Amersham, Buckinghamshire, UK).

\section{Assessment of efflux function}

Cells $\left(5 \times 10^{5}\right)$ were incubated in $100 \mathrm{ng} / \mathrm{ml} \mathrm{Rh123}$ (Dr. I Bertoncello, Peter MacCallum Cancer Centre) in the presence or absence of $10 \mu \mathrm{M}$ verapamil (Knoll, Lane Cove, Australia) and incubated at $37^{\circ} \mathrm{C}$ for $20 \mathrm{~min}$. Cells were then pelleted and allowed to efflux without verapamil for a further $2 \times 15 \mathrm{~min}$. The efflux of ${ }^{3} \mathrm{H}$-vinblastine was assessed using a modified protocol previously published. ${ }^{47}$ Cells $\left(4 \times 10^{6}\right)$ were incubated with $25 \mathrm{ng} / \mathrm{ml}^{3} \mathrm{H}$-vinblastine (Moravek Biochemicals, Brea, CA, USA) at 
$37^{\circ} \mathrm{C}$ for $1 \mathrm{~h}$, washed, lysed in $0.2 \mathrm{~N} \mathrm{NaOH}$ at $37^{\circ} \mathrm{C}$ for $1 \mathrm{~h}$ and neutralized in $0.2 \mathrm{~N} \mathrm{HCl}$. Lysates were then measured in a $\beta$-counter and results expressed as a percentage of sample containing ${ }^{3} \mathrm{H}$-vinblastine alone. For time-course analysis of ${ }^{3} \mathrm{H}$-vinblastine efflux, cells were labeled as above and then pelleted, washed and resuspended in medium with $25 \mu \mathrm{g} / \mathrm{ml}$ unlabeled vinblastine and allowed to efflux against the concentration gradient at $37^{\circ} \mathrm{C}$, with aliquots taken and lysed as above at time points up to $30 \mathrm{~min}$.

\section{Cytotoxicity and viability assays}

Cells were cultured in the presence or absence of cytotoxic stimuli and trypan blue-exclusion assays were performed as previously described. ${ }^{48}$ Annexin staining was performed by incubating treated cells in annexin-Valexa 568 (Roche, Mannheim, Germany) according to the manufacturer's instructions and read by flow cytometry. Results were calculated as the percentage of cells that were viable by forward scatter-FL3 profile. Complement treatment of cells and ${ }^{51}$ chromium release assays were performed as previously described. ${ }^{38} \mathrm{P}$-gp reversal assays were performed by preincubating cells in anti-P-gp monoclonal antibodies (16 $\mu \mathrm{g} / \mathrm{ml}$ UIC2 (Immunotech, Marseille, France) or $100 \mu \mathrm{g} / \mathrm{ml}$ MRK16) for $1 \mathrm{~h}$ prior to addition of $50 \mathrm{ng} / \mathrm{ml}$ vincristine. Samples were then incubated for $24 \mathrm{~h}$ at $37^{\circ} \mathrm{C}$ and trypan counted as above. Clonogenic assays and propidium iodide staining for cell cycle analysis cells were performed as previously described. ${ }^{48,49}$ Histological examination of drug-treated cells was performed using hematoxylin and eosin staining of cells adhered to glass slides by slow centrifugation (Cytospin 3, Shandon, UK).

\section{Caspase activity assays}

Caspase activity assays were performed using fluorogenic pNA substrates (Biomol, Plymouth Meeting, PA, USA). Cells $\left(2 \times 10^{6}\right)$ were treated with drug and then inhibitor-free lysates made using NP40 lysis buffer. ${ }^{41} A$ measure of $50 \mu \mathrm{g}$ of protein at $1 \mu \mathrm{g} / \mathrm{ml}$ was mixed with $50 \mu \mathrm{l}$ of BAADT buffer $\left(0.1 \mathrm{M}\right.$ HEPES, $0.05 \mathrm{M} \mathrm{CaCl}_{2}$ ) with or without $0.625 \mathrm{mM}$ pNA and incubated at $37^{\circ} \mathrm{C}$ for up to $2 \mathrm{~h}$, with readings taken at $405 \mathrm{~nm}$ on a plate reader.

\section{Cytochrome $c$ release}

Cells $\left(4 \times 10^{5}\right)$ were incubated in $40 \mu$ digitonin lysis buffer $(80 \mathrm{mM} \mathrm{KCl}$, $250 \mathrm{mM}$ sucrose, $400 \mu \mathrm{g} / \mathrm{ml}$ digitonin) for $1 \mathrm{~min}$ at $4^{\circ} \mathrm{C}^{50}$ Samples were centrifuged at $10000 \times g$ for $5 \mathrm{~min}$ and the supernatant removed for analysis. Proteins were separated by SDS-PAGE (15\%), blotted onto Immobilon-P membrane (Millipore, Bedford, MA, USA) and probed with anticytochrome $c$ antibody $7 \mathrm{H} 8.2 \mathrm{C} 12$ (BD Pharmingen, Lane Cove, Australia), followed by secondary labeling with HRP-conjugated antimouse antibody (DAKO, Glostrup, Denmark) and detection using ECL (Amersham, Buckinghamshire, UK).

\section{Acknowledgements}

We thank Igor Roninson, Paul Roepe and Anthony Dear for providing reagents, Ralph Rossi and Andrew Fryga for technical support and Nigel Waterhouse for helpful discussions. RWJ is a Wellcome Trust Senior Research Fellow and MJS is a Principal Research Fellow of the National Health and Medical Research Council of Australia (NH\&MRC). This work is supported by a project grant from the NH\&MRC, the Anti-Cancer Council of Victoria (ACCV) and the Wellcome Trust.

\section{References}

1. Gottesman MM and Pastan I (1993) Biochemistry of multidrug resistance mediated by the multidrug transporter. Annu. Rev. Biochem. 62: 385-427

2. Cordon-Cardo C, O'Brien JP, Casals D, Rittman-Grauer L, Biedler JL, Melamed MR and Bertino JR (1989) Multidrug-resistance gene (Pglycoprotein) is expressed by endothelial cells at blood-brain barrier sites. Proc. Natl. Acad. Sci. USA 86: 695-698

3. Thiebaut F, Tsuruo T, Hamada H, Gottesman MM, Pastan I and Willingham MC (1987) Cellular localization of the multidrug-resistance gene product $\mathrm{P}$ glycoprotein in normal human tissues. Proc. Natl. Acad. Sci. USA 84: 77357738

4. Chaudhary PM and Roninson IB (1991) Expression and activity of Pglycoprotein, a multidrug efflux pump, in human hematopoietic stem cells. Cell 66: 85-94

5. Ueda K, Cardarelli C, Gottesman MM and Pastan I (1987) Expression of a fulllength CDNA for the human 'MDR1' gene confers resistance to colchicine, doxorubicin, and vinblastine. Proc. Natl. Acad. Sci. USA 84: 3004-3008

6. Doige CA, Yu X and Sharom FJ (1992) ATPase activity of partially purified Pglycoprotein from multidrug-resistant Chinese hamster ovary cells. Biochim. Biophys. Acta 1109: 149-160

7. Ambudkar SV, Lelong IH, Zhang J, Cardarelli CO, Gottesman MM and Pastan I (1992) Partial purification and reconstitution of the human multidrug-resistance pump: characterization of the drug-stimulatable ATP hydrolysis. Proc. Natl. Acad. Sci. USA 189: 8472-8476

8. Sarkadi B, Price EM, Boucher RC, Germann UA and Scarborough GA (1992) Expression of the human multidrug resistance $c D N A$ in insect cells generates a high activity drug-stimulated membrane ATPase. J. Biol. Chem. 267: 48544858

9. Shimabuku AM, Nishimoto T, Ueda K and Komano T (1992) P-glycoprotein. ATP hydrolysis by the N-terminal nucleotide-binding domain. J. Biol. Chem. 267: 4308-4311

10. Horio M, Gottesman MM and Pastan I (1988) ATP-dependent transport of vinblastine in vesicles from human multidrug-resistant cells. Proc. Natl. Acad. Sci. USA 85: 3580-3584

11. Sharom FJ, Yu X and Doige CA (1993) Functional reconstitution of drug transport and ATPase activity in proteoliposomes containing partially purified $\mathrm{P}$ glycoprotein. J. Biol. Chem. 268: 24197-24202

12. Higgins CF and Gottesman MM (1992) Is the multidrug transporter a flippase? Trends Biochem. Sci. 17: 18-21

13. van Helvoort A, Smith AJ, Sprong H, Fritzsche I, Schinkel AH, Borst P and van Meer G (1996) MDR1 P-glycoprotein is a lipid translocase of broad specificity, while MDR3 P-glycoprotein specifically translocates phosphatidylcholine. Cell 87: $507-517$

14. Smyth MJ, Krasovskis E, Sutton VR and Johnstone RW (1998) The drug efflux protein, P-glycoprotein, additionally protects drug-resistant tumor cells from multiple forms of caspase-dependent apoptosis. Proc. Natl. Acad. Sci. USA 95: 7024-7029

15. Johnstone RW, Cretney E and Smyth MJ (1999) P-glycoprotein protects leukemia cells against caspase-dependent, but not caspase-independent, cell death. Blood 93: 1075-1085

16. Bezombes $C$, Maestre N, Laurent $G$, Levade T, Bettaieb A and Jaffrezou JP (1998) Restoration of TNF-alpha-induced ceramide generation and apoptosis in resistant human leukemia KG1a cells by the P-glycoprotein blocker PSC833. FASEB J. 12: 101-109

17. Robinson LJ, Roberts WK, Ling TT, Lamming D, Sternberg SS and Roepe PD (1997) Human MDR 1 protein overexpression delays the apoptotic cascade in Chinese hamster ovary fibroblasts. Biochemistry 36: 11169-11178

18. Ruth AC and Roninson IB (2000) Effects of the multidrug transporter P-glycoprotein on cellular responses to ionizing radiation. Cancer Res. 60: 2576-2578

19. Johnstone RW, Ruefli AA and Lowe SW (2002) Apoptosis: a link between cancer genetics and chemotherapy. Cell 108: 153-164

20. Pallis M and Russell N (2000) P-glycoprotein plays a drug-efflux-independent role in augmenting cell survival in acute myeloblastic leukemia and is associated with modulation of a sphingomyelin-ceramide apoptotic pathway. Blood 95: 2897-2904

21. Pallis M, Turzanski J, Grundy M, Seedhouse C and Russell N (2003) Resistance to spontaneous apoptosis in acute myeloid leukaemia blasts is 
associated with P-glycoprotein expression and function, but not with the presence of FLT3 internal tandem duplications. Br. J. Haematol. 120: 1009-1016

22. Gollapud S and Gupta S (2001) Anti-P-glycoprotein antibody-induced apoptosis of activated peripheral blood lymphocytes: a possible role of $\mathrm{P}$ glycoprotein in lymphocyte survival. J. Clin. Immunol. 21: 420-430

23. Bunting KD, Galipeau J, Topham D, Benaim E and Sorrentino BP (1998) Transduction of murine bone marrow cells with an MDR1 vector enables ex vivo stem cell expansion, but these expanded grafts cause a myeloproliferative syndrome in transplanted mice. Blood 92: 2269-2279

24. Bunting KD, Zhou S, Lu T and Sorrentino BP (2000) Enforced P-glycoprotein pump function in murine bone marrow cells results in expansion of side population stem cells in vitro and repopulating cells in vivo. Blood 96: 902-909

25. Muller M, Bakos E, Welker E, Varadi A, Germann UA, Gottesman MM, Morse BS, Roninson IB and Sarkadi B (1996) Altered drug-stimulated ATPase activity in mutants of the human multidrug resistance protein. J. Biol. Chem. 271: 1877-1883

26. Kessel D, Beck WT, Kukuruga D and Schulz V (1991) Characterization of multidrug resistance by fluorescent dyes. Cancer Res. 51: 4665-4670

27. Lee JS, Paull K, Alvarez M, Hose C, Monks A, Grever M, Fojo AT and Bates SE (1994) Rhodamine efflux patterns predict P-glycoprotein substrates in the National Cancer Institute drug screen. Mol. Pharmacol. 46: 627-638

28. Petriz J, O'Connor JE, Carmona M and Garcia-Lopez J (1997) Is rhodamine 123 an appropriate fluorescent probe to assess P-glycoprotein mediated multidrug resistance in vinblastine-resistant $\mathrm{CHO}$ cells? Anal. Cell. Pathol. 14 $129-140$

29. Hamel E and Covell DG (2002) Antimitotic peptides and depsipeptides. Curr. Med. Chem. Anti-Cancer Agents 2: 19-53

30. Wang LG, Liu XM, Kreis W and Budman DR (1999) The effect of antimicrotubule agents on signal transduction pathways of apoptosis: a review. Cancer Chemother. Pharmacol. 44: 355-361

31. Chang BD, Broude EV, Dokmanovic M, Zhu H, Ruth A, Xuan Y, Kandel ES Lausch E, Christov K and Roninson IB (1999) A senescence-like phenotype distinguishes tumor cells that undergo terminal proliferation arrest after exposure to anticancer agents. Cancer Res. 59: 3761-3767

32. Nabha SM, Mohammad RM, Dandashi MH, Coupaye-Gerard B, Aboukameel A, Pettit GR and Al-Katib AM (2002) Combretastatin-A4 prodrug induces mitotic catastrophe in chronic lymphocytic leukemia cell line independent of caspase activation and poly(ADP-ribose) polymerase cleavage. Clin. Cancer Res. 8: 2735-2741

33. Mechetner EB and Roninson IB (1992) Efficient inhibition of P-glycoproteinmediated multidrug resistance with a monoclonal antibody. Proc. Natl. Acad. Sci. USA 89: 5824-5828

34. Juliano RL and Ling V (1976) A surface glycoprotein modulating drug permeability in Chinese hamster ovary cell mutants. Biochim. Biophys. Acta 455: $152-162$

35. Takara K, Sakaeda T, Yagami T, Kobayashi H, Ohmoto N, Horinouchi M, Nishiguchi K and Okumura K (2002) Cytotoxic effects of 27 anticancer drugs in HeLa and MDR1-overexpressing derivative cell lines. Biol. Pharm. Bull. 25: $771-778$

36. Smeets ME, Raymakers RA, Vierwinden G, Pennings AH, Boezeman J, Minderman $\mathrm{H}$ and de Witte TM (1999) Idarubicin DNA intercalation is reduced by MRP1 and not Pgp. Leukemia 13: 1390-1398
37. Peart MJ, Tainton KM, Ruefli AA, Dear AE, Sedelies KA, O'Reilly LA, Waterhouse NJ, Trapani JA and Johnstone RW (2003) Novel mechanisms of apoptosis induced by histone deacetylase inhibitors. Cancer Res. 63: $4460-4471$

38. Johnstone RW, Tainton KM, Ruefli AA, Froelich CJ, Cerruti L, Jane SM and Smyth MJ (2001) P-glycoprotein does not protect cells against cytolysis induced by pore-forming proteins. J. Biol. Chem. 276: 16667-16673

39. Azzaria M, Schurr E and Gros P (1989) Discrete mutations introduced in the predicted nucleotide-binding sites of the mdr1 gene abolish its ability to confer multidrug resistance. Mol. Cell. Biol. 9: 5289-5297

40. Johnstone RW, Ruefli AA and Smyth MJ (2000) Multiple physiological functions for multidrug transporter P-glycoprotein? Trends Biochem. Sci. 25: $1-6$

41. Ruefli AA, Tainton KM, Darcy PK, Smyth MJ and Johnstone RW (2002) P-glycoprotein inhibits caspase-8 activation but not formation of the death inducing signal complex (disc) following Fas ligation. Cell. Death Differ. 9: 1266-1272

42. Bouillet $P$, Metcalf $D$, Huang DC, Tarlinton DM, Kay TW, Kontgen F, Adams JM and Strasser A (1999) Proapoptotic Bcl-2 relative Bim required for certain apoptotic responses, leukocyte homeostasis, and to preclude autoimmunity. Science 286: 1735-1738

43. Puthalakath H, Villunger A, O'Reilly LA, Beaumont JG, Coultas L, Cheney RE, Huang DC and Strasser A (2001) Bmf: a proapoptotic BH3-only protein regulated by interaction with the myosin $\mathrm{V}$ actin motor complex, activated by anoikis. Science 293: 1829-1832

44. Ruefli AA, Bernhard D, Tainton KM, Kofler R, Smyth MJ and Johnstone RW (2002) Suberoylanilide hydroxamic acid (SAHA) overcomes multidrug resistance and induces cell death in P-glycoprotein-expressing cells. Int. J. Cancer 99: 292-298

45. Ruefli AA, Ausserlechner MJ, Bernhard D, Sutton VR, Tainton KM, Kofler R, Smyth MJ and Johnstone RW (2001) The histone deacetylase inhibitor and chemotherapeutic agent suberoylanilide hydroxamic acid (SAHA) induces a novel cell death pathway characterized by Bid cleavage and ROS production. Proc. Natl. Acad. Sci. USA 98: 10833-10838

46. Yin XM, Wang K, Gross A, Zhao Y, Zinkel S, Klocke B, Roth KA and Korsmeyer SJ (1999) Bid-deficient mice are resistant to Fas-induced hepatocellular apoptosis. Nature 400: 886-891

47. Schaich M, Neu S, Beck J, Gekeler V, Schuler U and Ehninger G (1997) A novel method for direct and fluorescence independent determination of drug efflux out of leukemic blast cells. Leuk. Res. 21: 933-940

48. Ruefli AA, Smyth MJ and Johnstone RW (2000) HMBA induces activation of a caspase-independent cell death pathway to overcome P-glycoproteinmediated multidrug resistance. Blood 95: 2378-2385

49. Tainton KM, Ruefli AA, Smyth MJ and Johnstone RW (2000) Equivalent death of P-glycoprotein expressing and nonexpressing cells induced by the protein kinase $\mathrm{C}$ inhibitor staurosporine. Biochem. Biophys. Res. Commun. 276: 231-237

50. Waterhouse NJ, Goldstein JC, von Ahsen O, Schuler M, Newmeyer DD and Green DR (2001) Cytochrome $c$ maintains mitochondrial transmembrane potential and ATP generation after outer mitochondrial membrane permeabilization during the apoptotic process. J. Cell. Biol. 153: $319-328$ 